\title{
Igazságosan vagy testvériesen? Szerzői szerepek és társszerzői részesedések a tudományos publikálásban
}

\author{
Schubert András
}

MTA Könyvtár és Információs Központ, Tudománypolitikai és Tudományelemzési Osztály, Budapest

\begin{abstract}
Az elmúlt évtizedekben jelentősen megnövekedett a társszerzős és ezen belül is a sokszerzős cikkek aránya a tudományos publikációk között. A cikk ennek a jelenségnek az okaival és a tudománymetriai elemzéseket illető következményeivel foglalkozik. Kitér a publikációknak és az idézeteknek a társszerzők közötti szétosztásának lehetőségeire, valamint a h-index és az önidézettség értelmezésének problémáira társszerzős cikkek esetében. Orv. Hetil., 2016, $157(13), 512-516$.
\end{abstract}

Kulcsszavak: tudománymetria, szerzőség, társszerzőség

\section{Equally or equitably? Author roles and co-author shares in scientific publication}

In the last decades the share of co-authored and, particularly, multi-authored papers has increased immensely. The paper deals with the causes and consequences of this phenomenon, specifically with those connected with scientometric analyses. Possibilities for fractional count of publications and citations, as well as problems of interpreting $\mathrm{h}$-index and self-citation in case of multi-authored papers are focused upon.

Keywords: scientometrics, authorship, co-authorship

Schubert, A. [Equally or equitably? Author roles and co-author shares in scientific publication]. Orv. Hetil., 2016, $157(13), 512-516$.

(Beérkezett: 2016. febuár 7.; elfogadva: 2016. február 25.)

Az elmúlt néhány évtized tudományos kutatásának egyik legfőbb jellegzetessége az együttmúködések szerepének elképesztő megnövekedése. A növekedés mértéke ugyan határozottan függ a földrajzi és a kutatási területtől, de egyaránt jelen van országok, intézmények és egyéni kutatók szintjén.

A Thomson-Reuters Web of Science adatbázis körülbelül 12000 folyóiratának adatai alapján 1980 és 2012 között az átlagos szerzőszám több mint kétszeresére nőtt [1] (1. ábra). Az orvosi szakirodalomra a Medline/ PubMed statisztikái szinte tizedesre megegyező eredményeket mutatnak [2].

Az átlagértékek csak tompítva tükrözik azt a változást, ami a cikkek szerzőinek maximális számában mutatko-

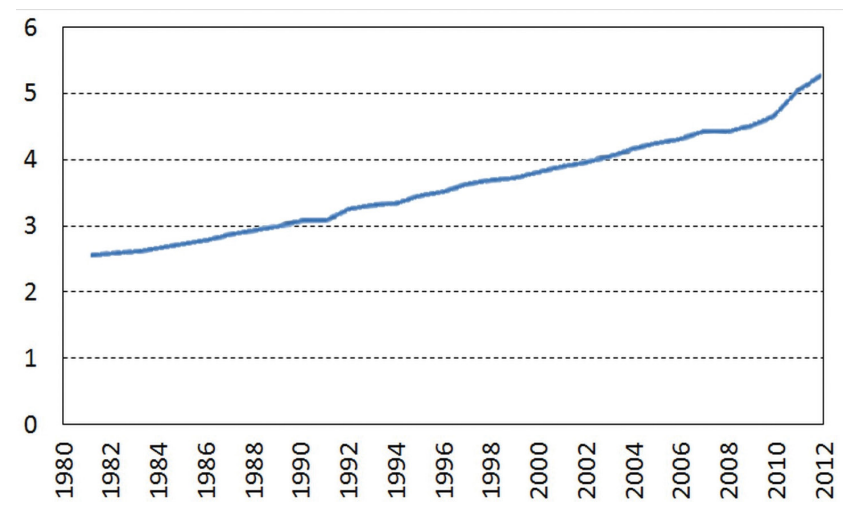

1. ábra $\quad$ A folyóiratcikkek átlagos szerzőszámának alakulása 1981-2012 között (A Science Watch 2013. szeptemberi adatai alapján [1]) 
zott. A Web of Science adatai szerint a 2010-es évekre a 100 vagy annál több szerző által jegyzett cikkek száma az évi 1000-et közelíti [3]. Ezek többsége a fizikai tudományok (főként a nagy energiájú részecskefizika) területéről származik, de az orvosbiológiai területek részesedése is $10 \%$ körüli.

\section{Szerzői szerepek}

$\mathrm{Az}$ együttmúködés tényében nemigen lehet kivetnivalót találni még az említett extrém esetekben sem. Határozott jelei mutatkoznak azonban annak, hogy a hosszú (vagy akár a viszonylag rövidebb) szerzői listákra olyan kutatók nevei is felkerülnek, akiknek részvétele, szerepe a cikket eredményező kutatásban kérdéses. Természetesen ez a jelenség nem új. Egyes intézményvezetők publikációs jegyzékét régóta bővítették „tiszteletbeli” szerzőségek, noha ezt a gyakorlatot hivatalosan mindig is helytelenítették. Az érdemi szerzők is kezdeményezik olykor olyan befolyásos kutatók, „húzónevek” társszerzői részvételét, akiktől a cikk kedvezőbb elbírálását vagy fogadtatását remélik.

A szerzőség kritériumait illetően az orvosi szakirodalomban az ICMJE (International Committee of Medical Journal Editors) ajánlásait [4] tekinthetjük mértékadónak. Eszerint szerzőnek az a személy tekinthető, aki

1) lényegesen hozzájárult a munka kiötléséhez vagy megtervezéséhez, illetve az adatok gyưjtéséhez, elemzéséhez vagy értékeléséhez; ÉS

2) részt vett a cikk megfogalmazásában vagy önálló szellemi tartalommal járult hozzá a végleges forma kialakításához; ÉS

3 ) jóváhagyta a publikálásra kész változatot; ÉS

4) hozzájárult ahhoz, hogy számon kérhető legyen a cikk bármely részének pontosságával vagy alaposságával kapcsolatos kérdések megfelelő vizsgálatának vagy megoldásának biztosításáért.

A dolog természeténél fogva nehéz megbízható adatokat találni a nem kellően megalapozott érdemekkel rendelkező „fantomszerzők” arányára a tudományos cikkek szerzői között, de az általános vélekedés az, hogy ez az arány az utóbbi évtizedekben jelentősen nőtt, ha talán nem is az átlagos szerzőszám-növekedéssel azonos mértékben.

A szerzőséggel kapcsolatos problémákkal, megoldási javaslatokkal foglalkozó szakirodalom mindazonáltal bőséges. Marusic és mtsai [5] 123 ilyen témájú vizsgálat alapján készítettek összefoglaló cikket. A főként az orvosbiológiai és társadalomtudományi szakirodalom szerzőségi kérdéseivel foglalkozó vizsgálatokból négy olyan problémakör rajzolódik ki, amely minden szakterületen közös:

1) a szerzőségről alkotott felfogás, annak definíciója és gyakorlata;

2) a szerzők sorrendjének meghatározása;

3) etikus és etikátlan szerzői gyakorlatok;
4) a kutatókkal együttmúködő diákok és nem kutató munkatársak szerzőségének kérdései.

A kérdőíves vizsgálatokban megkérdezett kutatók körülbelül egyharmada számolt be arról, hogy pályája során találkozott a szerzőségnek számára elfogadhatatlan felfogásával. Az orvosi folyóiratok megkérdezett szerkesztői szerint a beküldött kéziratokban 1\%-tól 65\%-ig terjedt azoknak a szerzőknek az aránya, akik nem feleltek meg az ICMJE-kritériumoknak. A szélsőségesen tág tartomány a látszólag precíz kritériumok értelmezési bizonytalanságát, és általában a szerzőséggel kapcsolatos kérdések eldöntésének nehézségeit jelzi.

Egy kérdés komolyságát mi sem jelzi jobban, mint hogy humor forrásává is válik. A tudományos humor kimeríthetetlen forrása, az Annals of Improbable Research közölte Lundberg és „munkatársai” (az idézőjel jelentősége hamarosan kiderül) cikkét [6], amely azt sugallja, hogy a szerzők számának emelkedése az entrópia sajnálatos növekedését eredményezi. (Nem teszik hozzá, csak én következtetem, hogy ezzel talán a klímaváltozásért is felelősség terheli...) Javaslatként - a folyóirat alapelvéhez hűen tréfásan, de elgondolkodtatva - háromra korlátoznák egy cikk lehetséges szerzőinek a számát, a többiektől azt kérik, hogy önként lépjenek vissza ettől a megtiszteltetéstől. Úgy vélik, hogy a tudományos cikkek szerzőinek egy része „rejtélyes közremúködő”, már ami a cikk létrejöttében játszott szerepüket illeti. Magát a cikket 35 szerző jegyzi, akik közül - a cikk 1. táblázata szerint - 31 „rejtélyes közremúködő”. Őket a tényleges szerzők kérték fel társszerzőnek, és ők ezt elfogadták, a szerzők szerint többen úgy, hogy nem is voltak vele egészen tisztában, mit is vállalnak. Az egyik „rejtélyes közremúködő” visszalépett, amiért a szerzők külön lábjegyzetben mondtak neki köszönetet.

És ami nem vicc: a cikkel kapcsolatos keresgélés során bukkantam rá arra, hogy az egyik „rejtélyes közremúködő" az egyetemi honlapján (a pontos forrást ez alkalommal tapintatból nem adom meg) ezzel a cikkel publikációs listájának teljes értékü elemeként büszkélkedik.

A szerzőszám növekedésének és az azzal kapcsolatos „túlkapásoknak” az okai sokrétüek.

Az egyre nagyobb fokú specializáció miatt az eredményes kutatáshoz egyre inkább szükség van a különféle szaktudású kutatók együttmúködésére. Ez fokozottan érvényes az interdiszciplináris kutatási területeken (amelyek súlya egyre növekszik), de igaz a hagyományosan egyetlen szakterületre korlátozódónak tekintett kutatásokra is.

Egyes kutatástámogatási rendszerek (gondolok föként az EU pályázataira) kifejezetten megkövetelik a nemzetközi együttmúködést. Ez erősen motiválja a résztvevőket együttmúködő partnerek keresésére akkor is, ha az eredeti elképzelés szerint a kutatás a nélkül is kivitelezhető lett volna.

Természetesen az okok között - különösen, ami a viszszaéléseket illeti - fontos szerepet játszik a „publish or perish" szemlélet térhódítása is. Bár sokak ezt a szemlé- 
letet a tudománymetria rovására írják, érdemes megjegyezni, hogy Garfield szerint [7] ez a kifejezés a tudománnyal kapcsolatban elöször Logan Wilson könyvében [8] tûnt fel 1942-ben, tehát évtizedekkel a tudománymetria megjelenése előtt. A tudománymetria szerepe (mások szerint búne) legfeljebb az, hogy ezt a szemléletet eredményesen szolgálta (kiszolgálta). A tudománymetria elöremutató szerepe szerintem pontosan abban áll, hogy megmutatja a tudomány mérhető aspektusainak sokrétüségét. Ezzel relativizálja és kontextusba helyezi az egyes aspektusok szűk hatósugarát. A „publish or perish”, „be cited or perish”, „have impact or perish”, "get connected or perish" szempontok külön-külön szegényesek, de együttesen és az emberi ítélóképesség szürőjén átengedve kiegyensúlyozott képet tudnak adni az egyénekről, csoportokról, intézményekről, vagy bármilyen más vizsgált egységekról.

A tudománymetriának - függetlenül attól, hogy volt-e szerepe a szerzőszám módfeletti növekedésében, és ha igen, akkor milyen - mindenképpen feladata, hogy megfelelő mutatószámokat találjon a sokszerzős cikkek kezelésére.

\section{A publikációk száma}

A publikációk számának meghatározása során a társszerzôs cikkek esetében a tudománymetria kezdeti időszakában háromféle eljárás volt szokásos:

1. Minden cikket minden társszerzőnek teljes értékben könyvelünk el („full credit”). Kevés társszerző esetében ez az eljárás akár méltányosnak is mondható. A tudománymetria klasszikus cikkei (például Lotka [9]) ezt használták. Természetesen ez az eljárás „túlszámláláshoz" vezet, vagyis a szerzói produktivitások összege az összpublikációszám többszöröse lehet. Ezt az adatok további feldolgozásánál figyelembe kell venni.

2. Minden cikket kizárólag az első szerzőnek írunk jóvá. Ez az eljárás fơként abból a kényszerüségből adódott, hogy egyes bibliográfiai adatforrások a többszerzős cikkeket „Első szerző et al.” formában tüntették fel. A produktivitási adatok ilyenkor összegezhetők, de a módszernek bármiféle létalapja csakis azokon a szakterületeken van, ahol az első szerzőségnek kiemelt szerepe van. A matematikában vagy a fizikában, ahol az alfabetikus szerzősorrend a szokásos, ez az eljárás súlyosan és jóvátehetetlenül torzít.

3. A cikkeket a társszerzók között egyenlő arányban osztjuk szét. Látszólagos igazságossága ellenére ez a módszer is erősen torzíthat. (Gondoljunk a „rejtélyes közremúködők" fenti példájára!)

A későbbiekben számos próbálkozás történt a módszertan finomítására. Az alapprobléma természetesen a szerzői hozzájárulások megbecsülése. A legfontosabb tudnivaló az, hogy ez erôsen szakterületfüggő. Szakterületfüggő az, hogy egyáltalán ki számíthat szerzőnek (az orvosbiológiai területen a [4] ajánlás tekinthető mértékadónak), és a szerzők sorrendje is. Az orvosbiológiai te- rületen az első és az utolsó szerzőnek van kitüntetett szerepe (az első a tényleges - föként a kísérletes - munka elvégzéséért, az utolsó a teljes munka koordinálásáért felelős), de más szakterületeken ez egyáltalában nem jellemző.

Vinkler [10] kérdőíves módszerrel kísérelte meg feltárni a kémiai publikációk szerzőinek hozzájárulási mértékét a cikkeikhez. Egyértelmúen kiderült, hogy a vizsgált mintában a szerzői sorrend tükrözi a hozzájárulás mértékét. Az utolsó szerzőségnek ezekben a publikációkban nem volt megkülönböztetett jelentősége. Az is kiderült, hogy a szerzők (a szerzői listán elfoglalt helytől függetlenül) kétségtelenül túlértékelik saját szerepüket. Az önértékelés alapján talált szerzői hozzájárulások öszszege a szerzők számával növekedett, és az 5 szerzős cikkek esetében megközelítette a 200\%-ot.

Újabban különféle algoritmusok (számtani, mértani, harmonikus haladvány stb.) szerint próbálják súlyozni a szerzői hozzájárulásokat egy „igazságosabb” elosztási séma kialakításának érdekében. Kim \& Kim alapos öszszehasonlító vizsgálata [11] a harmonikus elosztási sémát találta a legszélesebb körben alkalmazhatónak, amely a szerzői sorszám reciproka szerint számítja a szerzői hozzájárulás arányát $[12,13]$. Ök is hangsúlyozzák azonban, hogy az ilyen „automatikus” módszerek alkalmazásának kizárólag akkor van létjogosultsága, ha semmilyen más információ nincsen a szerzői hozzájárulások mértékéről.

Az alfabetikus szerzői sorrend értelmetlenné tesz bármiféle algoritmikus megközelítést. Ugyanakkor az újabb vizsgálatok [14] szerint az olyan cikkek aránya, amelyek szerzői szigorú ábécérendben vannak, erőteljesen csökken: a húsz évvel ezelőtti 10\% körüli értéknek alig több mint harmadát éri már csak el. Terjed viszont a részleges ábécérend: a kiemelt (első és esetleg az utolsó) szerzők kivételével a többi szerző alfabetikus rendben található.

Sok folyóirat ma már megköveteli, hogy kéziratok benyújtásakor a szerzők a szerzői szerepeket, illetve esetleg a hozzájárulások mértékét is megadják. Ez kétségtelenül felhasználható információ, de abszolút hitelessége és objektivitása a korábban mondottak értelmében legalábbis megkérdőjelezhető.

Mindezek alapján azt mondhatjuk, hogy egyetemesen jól használható módszer a szerzői hozzájárulás arányának becslésére nincsen, viszont számos kidolgozott és megvizsgált módszer áll rendelkezésre, amelyek közül a szakterület, illetve a vizsgált minta sajátosságainak és mindenekelőtt a konkrét elemzési feladat céljainak megfelelően választhatunk.

\section{Idézettség}

A publikációknak a szerzők közötti szétosztásának problémái eltörpülnek ahhoz képest, amibe akkor ütközünk, ha a publikációkra kapott idézeteket próbáljuk a szerzők között szétosztani. 
Könnyen elképzelhető például, hogy egy cikkre kapott idézetek döntô többsége a cikk egy olyan részletére (mérési adat, értékelési módszer stb.) vonatkozik, amely egyértelmúen az egyik, számszerúen kicsiny hozzájárulási aránnyal rendelkező szerző munkája. Lehetséges-e, értelmes-e ezt valamilyen módon figyelembe venni a cikk idézettségének értékelésénél?

További problémákat okoz, ha az idézeteket nem öszszesítve számolnánk, hanem - ahogyan az a legtöbb esetben célszerü - az egy cikkre kapott átlagos idézetszámot értékelnénk. Ha az idézeteket a publikációhoz való hozzájárulásuk arányában osztanánk el a szerző́k között, akkor az idézet/publikáció hányados végeredményben a súlyozás módjától független lenne. Különböző súlyfaktorok használata viszont nagymértékben áttekinthetetlenné tenné az értékelést.

Az elmondottak miatt a kapott idézeteknek a szerzők közötti szétosztására az irodalom nem kínál követhetó eljárást, ezért azt célszerű elkerülni.

\section{$\mathrm{H}$-index}

A h-index bevezetésével Hirsch [15] minden képzeletet felülmúló hullámokat kavart, amelyeket azóta is rengetegen próbálnak meglovagolni. Tucatjával jelentek meg az index módosított - a szerzőjük szerint nyilván javított változatai, amelyek az eredeti index valamely vélt vagy valódi fogyatékosságát igyekeznek orvosolni. Az egyik fó támadási pont éppen az, hogy a h-index nem tesz különbséget az egy- és többszerzős cikkek között (voltaképpen a „full credit” módszert követi). Mivel a h-index a publikációk számát és az idézettséget is magában foglalja, a többszerzős cikkek kezelésében mindkét mutatószámmal kapcsolatos problémák halmozottan jelentkeznek. A szerzők reményei szerint ,javított” mutatószámok ezért többnyire legfeljebb csak érdekes szellemi konstrukcióknak tekinthetók.

Egy ilyen érdekes megoldást maga Hirsch is javasolt a társszerzős cikkek figyelembevételére [16]. Az ő elgondolása szerint egy szerző „h-magjába” (vagyis a h-index értékének megfelelő h számú legidézettebb cikkek közé) csak azokat a cikkeket számítsuk be, amelyek minden egyes társszerző h-magjába beletartoznak. Ezzel a megoldással nem növeli egy szerző h-indexét az olyan a cikk, amelyet egy nagy idézettségü (és h-indexû́) szerzőtárssal írt, és neki nem tartozik a legidézettebb cikkei közé. Ez a módszer mintegy intézményesíti a „Máté-effektust" („akinek van, annak adatik, akinek nincs, attól az is elvétetik, amije van”). Amellett, hogy a módszer ,igazságossága" (vagy inkább azt mondanám, relevanciája) megkérdőjelezhető, az index gyakorlati kiszámítása olyan munkaigényes, hogy Hirsch maga is jónak látta, hogy egy egyszerúsített változatot is javasoljon a cikkében. Ennek a tartalma azonban már sokkal kevésbé nyilvánvaló. Mindezek alapján nem meglepő, hogy Hirschnek ez az ötlete nagyságrendekkel kevesebb követőre talált, mint az eredeti h-index.

\section{Önidézetek}

A többszerzős cikkek esetében felülvizsgálatra szorul az önidézetek értelmezése is. Az önidézés szigorú definíciója szerint önidézetről beszélünk, ha az idéző és az idézett cikknek van legalább egy közös szerzője. Nyilvánvalóan azonban más jellegú az önidézés akkor, ha egy egyszerzős cikk szerzője idézi egy másik egyszerzős cikkét (sietek hozzátenni, hogy természetesen önmagában ez sem elítélendő cselekedet), mint ha két százszerzős cikknek van egy közös szerzője.

A fenti szigorú definíción enyhíthetünk például azáltal, hogy az „igen-nem” megkülönböztetés helyett az önidézettség 0 és 1 közötti mértékét definiáljuk az idéző és idézett cikk szerzői halmazának átfedése szerint [17]. A mutatószám értéke 0 , ha az idéző és idézett cikknek nincs közös szerzője, l, ha a két szerzői lista megegyezik.

Az így definiált mutatószám (jelöljük x-szel) használatával természetesen körültekintően kell bánni. Itt is (mint minden tudománymetriai elemzésnél) mindenekelőtt az elemzés céljára kell tekintettel lennünk. Ha cikkek idézettségét vizsgáljuk, és figyelembe akarjuk venni az önidézettséget, akkor minden egyes kapott idézetet 1-x értékűnek számolhatunk. Ugyanígy járhatunk el például a folyóiratok önidézettséggel korrigált impaktfaktorának kiszámításánál.

Ha azonban egyes kutatók vagy kutatócsoportok idézettsége az elemzés tárgya, akkor indokoltnak látszik az a megoldás, hogy azokat az idéző cikkeket, amelynek szerzôi között szerepel a vizsgált személy vagy a vizsgált csoport valamely tagja, 0 súllyal vegyük figyelembe (x értékétől függetlenül), a többire használhatjuk az l-x értéket.

\section{Zárszó}

A tudományos együttmúködés tárgyi szükségessége és a publikálási kötelezettség egzisztenciális kényszere együttesen alakították ki a többszerzős (esetenként sokszerzős) publikálás mára uralkodóvá váló gyakorlatát. Lehetséges, hogy "metria”, vagyis a tudományos kutatás eredményességének mutatószámok alapján történő megítélése szerepet játszott a szerzőszám esetenként indokolatlan emelkedésében. Az azonban vitathatatlan, hogy szerepet kell vállalnia a többszerzős cikkek értékelésével, elemzésével kapcsolatos problémák megoldásában. Az ilyen irányú igyekezetben nincs hiány, de tudomásul kell venni, hogy nincsenek egyetemes érvényességü, csalhatatlan módszerek és megoldások. Rendelkezésre áll egy bőséges eszköztár, amelyből a konkrét feladat sajátosságainak megfelelően kell kiválasztani a legmegfelelőbb eszközt.

Anyagi támogatás: A szerző köszöni az FP7-SSH-2013-2 \#613202 (IMPACT-EV) projekt támogatását. 
A cikk végleges változatát a szerző elolvasta és jóváhagyta.

Érdekeltségek: A szerzőnek nincsenek érdekeltségei.

\section{Irodalom}

[1] http://sciencewatch.com/articles/single-author-papers-waning-share-output-still-providing-tools-progress

[2] https://www.nlm.nih.gov/bsd/authorsl.html

[3] http://archive.sciencewatch.com/newsletter/2012/201207/ multiauthor_papers/

[4] http://www.icmje.org/recommendations/browse/roles-and responsibilities/defining-the-role-of-authors-and-contributors. html

[5] Marusic, A., Bosnjak, L., Jeroncic, A.: A systematic review of research on the meaning, ethics and practices of authorship across scholarly disciplines. PLoS ONE, 2011, 6(9) e23477.

[6] Lundberg, A., Aguilera, A., Cappozzo, A., et al.: Entropy in the list of authors of scientific papers. Ann. Improb. Res., 2014, 20(1), 15-17. https://www.improbable.com/airchives/paperair/volume20/v20il/Entropy-Authors-AIR-20-1.pdf

[7] Garfield, E.: What is the primordial reference for the phrase 'Publish or Perish'? The Scientist, 1996, 10(12), 11.

[8] Wilson, L.: The Academic Man: A Study in the Sociology of a Profession. Oxford University Press, New York, 1942.
[9] Lotka, A. J.: The frequency distribution of scientific productivity. J. Wash. Acad. Sci., 1926, 16(12), 317-323.

[10] Vinkler, P.: Research contribution, authorship and team cooperativeness. Scientometrics, 1993, 26(1), 213-230.

[11] Kim, J., Kim, J.: Rethinking the comparison of co-authorship credit allocation schemes. J. Informetr., 2015, 9(3), 667-673.

[12] Hagen, N. T.: Harmonic allocation of authorship credit: Sourcelevel correction of bibliometric bias assures accurate publication and citation analysis. PLoS ONE, 2008, 3(12), e4021.

[13] Hagen, N. T.: Harmonic publication and citation counting: sharing authorship credit equitably - not equally, geometrically or arithmetically. Scientometrics, 2010, 84(3), 785-793.

[14] Waltman, L.: An empirical analysis of the use of alphabetical authorship in scientific publishing. J. Informetr., 2012, 6(4), 700711.

[15] Hirsch, J. E.: An index to quantify an individual's scientific output. Proc. Natl. Acad. Sci. U.S.A., 2005, 102(46), 1656916572.

[16] Hirsch, J. E.: An index to quantify an individual's scientific research output that takes into account the effect of multiple coauthorship. Scientometrics, 2010, 85(3), 741-754.

[17] Schubert, A., Glänzel, W., Thijs, B.: The weight of author self-citations. A fractional approach to self-citation counting. Scientometrics, 2006, 67(3), 503-514.

(Schubert András, e-mail: schuba@iif.hu)

\section{Pályázati felhívás}

Professzor Dr. Fehér János munkássága, szakmai és erkölcsi hagyatéka páratlan és maradandó az orvostudományban. Ezért a Semmelweis Egyetem Általános Orvostudományi Kar II. sz. Belgyógyászati Klinika volt igazgatója, „A hepatológiai szabad gyökös és immunológiai vonatkozásai" című program vezetőjének, az Orvosi Hetilap főszerkesztőjének emlékére Alapítvány létesült. Az alapítványt a Fővárosi Bíróság 2011. március 7-én 11.335. sorszám alatt nyilvántartásba vette.

Dr. Fehér János Emlékére Alapítvány fö célja: a belgyógyászat, különösen a hepatológia szabad gyökös és immunológiai vonatkozásai témakörök kutatásának fejlesztése, támogatása, illetve ösztönzése oly módon, hogy a fiatal egyetemi oktatók és hallgatók az alapítvány kamatából részesüljenek. Az alapítvány célja olyan orvosok, PhD-hallgatók díjazása, akik kiemelkedő tudományos munkát végeznek és eredményeiket az Orvosi Hetilapban publikálják.

A dolgozatot „Dr. Fehér János pályázat” megjelölésével kell benyújtani.

A pályázatot 2016. április 5-ig lehet beküldeni a Kuratórium elnökének (Dr. Rácz Károly) vagy titkárának (Dr. Lengyel Gabriella) - Semmelweis Egyetem, II. sz. Belgyógyászati Klinika, 1088 Budapest, Szentkirályi u. 46. címre.

A pályázathoz mellékelni kell a pályázó önéletrajzát és a dolgozatot.

A dijjak odaítéléséről a kuratórium dönt. A dij átadására a Markusovszky ünnepségen kerül sor. Az ünnepségen a nyertes pályázó maximum 5-10 perces előadásban foglalja össze az eredményeit. 